\title{
Relation between the expression of E-cadherin, p53,c-erb-B2 (HER-2/neu) and steroid receptors (ER, PgR) in invasive ductal breast carcinoma with axillary lymph node metastases
}

\author{
Aksiller lenf nodu metastazlı invaziv duktal meme karsinomda E-cadherin, p53, c-erb-B2 (HER- \\ 2/neu) ve steroid reseptörleri (ER, PgR) ekspresyonu arasındaki ilişki
}

Nihal KILINÇ

\section{ABSTRACT}

Objective: This study explores the correlation between the expression of E-cadherin, p53 tumor suppressor gene, c-erb-B2 (HER-2/neu) and steroid receptors (ER, PgR) in invasive ductal breast carcinoma with axillary lymph node metastases.

Patients and Methods: We have investigated tumor samples from sixty patients with invasive ductal breast carcinoma. 30 of the patients had axillary lymph node metastases and 30 had no axillary lymph node metastases. Tumor tissues of these patients were evaluated by immunohistochemistry for E-cadherin, p53, c-erb-B2 (HER-2/neu) and steroid receptors (ER, PgR).

Results: E-cadherin staining was not expressed in 39 patients (65\%) with invasive ductal breast carcinoma. ER, PgR, p53, and c-erb-B2 signals were positive in 36 (60\%), 26 (43.3\%), 33 (55\%), and $29(48.3 \%)$ of the patients, respectively. PgR and c-erb-B2 expression was associated with lymph node metastases $(\mathrm{p}=0.009$, $\mathrm{p}=0.001$, respectively). No association was found between the reduced E-cadherin protein and age. The presence of E-cadherin was associated with axillary lymph node metastases and p53 ( $\mathrm{p}<0.009, \mathrm{p}<0.001$, respectively).

Conclusion: We found that, the $\mathrm{p} 53$ protein may play a role in regulation of E-cadherin protein expression in invasive ductal breast carcinomas with axillary lymph node metastases.

Keywords: Breast carcinoma, E-cadherin, p53, c-erb-B2, ER, PgR, Metastases

Nihal Kılınç

Department of Pathology, School of Medicine, Çanakkale Onsekiz Mart University, Çanakkale, Turkey

e-mail:nkilinc2013@hotmail.com

Submitted/Gönderilme: 10.01.2015

Accepted/Kabul: 28.03.2015

\section{ÖZET}

Amaç: Aksiller lenf nodu metastazlı invaziv duktal meme karsinomda E-cadherin, p53 tümör supressör gen, c-erbB-2 (HER2/neu) ve steroid reseptörleri (ER ve PgR) ekspresyonu arasındaki ilişkiyi araştırmak amaçlanmıştır.

Hastalar ve Yöntem: Bu çalışmada, 30 aksiller lenf nodu metastazlı ve 30 aksiller lenf nodu metastazı mevcut olmayan invaziv duktal meme karsinomlu 60 hasta immunokimyasal metodu kullanılarak E-cadherin ve c-erbB-2, ER ve PgR antikorları değerlendirildi.

Bulgular: İnvaziv duktal meme karsinomlu 60 hastanın 39'unda (\%65) E-cadherin ile boyanma tesbit edilmedi. Sirasıly ER, PgR, p53, ve c-erb-B2, 60 hastanın 36'ında (\%60), 60 hastanın 26'ında $(\% 43,3), 60$ hastanın 33'ünde (\%55), and 60 hastanın 29'unda $(\% 48,3)$ pozitif boyanma görüldü. $\mathrm{PgR}$ ve c-erb-B2 boyanması lenf nodu metastazı ile ilişkili idi (sırasıyla, $\mathrm{p}=0,009$, $\mathrm{p}=0,001)$. E-cadherin proteini ile yaş arasında ilişki görülmedi. E-cadherin ile lenf nodu metastazı ve p53 arasında ilişki görüldü (sirasiyla, $\mathrm{p}<0,009, \mathrm{p}<0,001$ ).

Sonuç: p53 proteini E-cadherin protein ekspresyonu gösteren aksiller lenf nodu metastazlı invaziv duktal meme karsinomda bir role sahiptir.

Anahtar kelimeler: Meme karsinomu, E-cadherin, p53, c-erb-B2, ER, PgR Metastaz

\section{Introduction}

Breast cancer is the most frequent cancer in women and the leading cause of cancer mortality in women worldwide [1-3]. $\mathrm{E}$ (epithelial)-cadherin is a $120 \mathrm{kDa}$ member of a family of transmembrane glycoproteins and is an epithelium specific cell-to-cell adhesion molecule. Immunohistochemical (IHC) studies have shown that all normal epithelial tissues strongly express E-cadherin at the cell membrane. Cell adhesion molecules are important in the regulation of cell 
differentiation and morphogenesis. It seems to play a crucial role in tumour invasion and metastasis [2,3]. In experimental systems cadherins decrease tumour invasions. Several groups have studied E-cadherin expression and its prognostic value in different tumour types and the down-regulation of E-cadherin expression in breast carcinomas has been found to correlate with grade of the tumor differentiation $[4,5]$.

One of the best known tumor suppressor genes is the p53 gene. It is located on chromosome 17 and encodes for a nuclear phosphoprotein that binds to DNA, preventing progression of the cell from the G1 to the S-phase in the cell cycle. Many reports have shown that overexpression of the p53 protein may be an indicator of poor prognosis in breast cancer, particullary if metastases are present in the axillary nodes [5,6]. c-erb-B2 is amplified in approximately $20 \%$ of breast cancers, and HER2 gene amplification in breast cancer has been associated with tumor invasiveness, progressive regional and distant metastases, and with an adverse prognosis. Breast cancer is a hormone-dependent tumor; the expression of ER and PgR provide important indicator for efficacy and prognosis in patients with endocrine therapies $[3,4,7]$.

In this study, we examined the patterns of E-cadherin, p53, c-erb-B2, ER and PgR expression in a series of invasive ductal breast carcinomas, with axillary lymph node metastases and compared these expression patterns with the expression in the primary tumours.

\section{Patients and Methods}

Material for this study was obtained from sixty samples of paraffin-embedded tumour tissues. 30 of the patients had axillary lymph node metastases and 30 had no axillary lymph node metastases. The samples were analysed for protein expression of p53 and E-cadherin. The mean age of the patients was 49.5 years (range 29 to 80 ).

After the review of hematoxylin and eosin (H\&E)stained slides from each patient, a representative block was chosen for the the whole population. Blocks were cut as 4- $\mu$ m-thick sections, placed on slides.

Clinical data and pathology reports for all 60 patients were analyzed to identify age, grade, lymph node status, expression of ER and PgR, and expression of c-erb-B2 and $\mathrm{p} 53$. Histologic grading of tumors was confirmed by the modified Richardson and Bloom method [8]. The expression of E-cadherin in normal ducts, primary tumors, and in the corresponding axillary lymph node metastases was analyzed individually in each patient. One section for each patient was examined histologically after hematoxylin and eosin staining to confirm the malignancy. Another section from each patient was used to examine the expression of E-cadherin.

The distribution of clinical, histological, and prognostic features of the patients is shown in Table I. Routine avidinbiotin complex IHC techniques [8] were used for the assessment of all antibodies shown in Table I. Positive and negative controls for each marker were used according to the supplier's data sheet (DAKO, Carpinteria, CA, USA; Labvision/Neomarkers, CA,USA). For each tumor, IHC was performed for ER, PR, and HER2 on a tumor block from both the SF group and on a second tumor block. All procedures were performed in-house using the Bench Mark XT system (Ventana Medical Systems,Inc., Tucson, AZ, USA) and the iView Detection Kit (Ventana, AZ, USA). All steps were automated according to the Bench Mark $\mathrm{XT}$ system. The complex for each reaction was visualized using 3-Amino-9Ethylcarbazole (AEC), counter-stained with hematoxylin, and examined under a light microscope. Tumors were registered as showing c-erbB-2, ER, PgR p53 and E-cadherin overexpression if more than $10 \%$ of the tumor cells were positive. E-cadherin expression in the epidermis was used as positive control. IHC scoring was performed in a blind fashion. E-cadherin was observed at cell-cell boundaries of breast cancer cells. E-cadherin expression IHC was semi-quantitatively analyzed according to the percentage of cells showing membrane positivity: 0,0 to $10 \% ;(-), 10$ to $30 \% ; 1+, 30$ to $70 \% ; 2+,>70 \%$.

Table I. Correlation of ER, PgR, p53 and c-erb-B2 positivity with lymphatic invansion.

\begin{tabular}{|c|c|c|c|c|c|}
\hline \multirow[t]{2}{*}{ Features } & \multicolumn{3}{|c|}{ LI-Positive } & LI-Negative & \multirow[t]{2}{*}{ P-value } \\
\hline & & $\begin{array}{c}\text { No. of } \\
\text { patients }\end{array}$ & $\%$ & No. of patients & \\
\hline \multirow[t]{2}{*}{ Age } & $>40$ & 24 & 52.2 & 22 & \multirow{2}{*}{${ }^{*} \mathrm{p}=0.542$} \\
\hline & $<40$ & 6 & 42.8 & 8 & \\
\hline \multicolumn{2}{|l|}{ Grade I } & 4 & 80,0 & 1 & \multirow{3}{*}{${ }^{* *} \mathrm{p}=0.586$} \\
\hline \multicolumn{2}{|l|}{ II } & 15 & 55.6 & 12 & \\
\hline \multicolumn{2}{|l|}{ III } & 11 & 39.2 & 17 & \\
\hline \multirow[t]{2}{*}{ ER } & $(+)$ & 19 & 52.8 & 17 & \multirow{2}{*}{${ }^{*} \mathrm{p}=0.598$} \\
\hline & $(-)$ & 11 & 45.9 & 13 & \\
\hline \multirow[t]{2}{*}{ PgR } & $(+)$ & 8 & 30.7 & 18 & \multirow{2}{*}{${ }^{*} \mathrm{p}=0.009$} \\
\hline & $(-)$ & 22 & 64.8 & 12 & \\
\hline \multirow[t]{2}{*}{ p53 } & $(+)$ & 19 & 57.6 & 14 & \multirow{2}{*}{${ }^{*} \mathrm{p}=0.194$} \\
\hline & $(-)$ & 11 & 40.8 & 16 & \\
\hline \multirow[t]{2}{*}{ c-erb-B2 } & $(+)$ & 21 & 72.5 & 8 & \multirow{2}{*}{${ }^{*} \mathrm{p}=0.001$} \\
\hline & $(-)$ & 9 & 29.1 & 22 & \\
\hline
\end{tabular}

LI: lymphatic invasion, ER: estrogen receptor, PgR:progesterone receptor, *Pearson Chi-Square, **Kolmogoro-Smirnov test 


\section{Statistical analysis}

All statistical analyses were performed on a personal computer with the SPSS 11.0 PC program. To compare categorical variations, Pearson's Chi-Square and the Kolmogorov-Smirnov tests were used. $P$ values of $p=0.05$ or less were considered statistically significant.

\section{Results}

The age range of these patients was 29-80 years (median, 49.5 years) at the time of surgery. Immunostaining for E-cadherin appeared as cell membranous staining in tumor cells (Figure 1). Myoepithelial and stromal cells did not express E-cadherin.

Membrane expression of E-cadherin was observed in 21 of $60(35 \%)$ invasive ductal breast carcinomas, and in 39 of $60(65 \%)$ there was a reduced expression. The status of the lymph node metastases, showed a reduced expression of E-cadherin in 25/30 (83.3\%) of patients who had lymph node metastases, versus in 14/30 (46.6\%) without lymph node metastases. A reduced expression of E-cadherin has been found in association with the histological grade of the carcinoma, the status of the metastases in the lymph nodes and the levels of $\mathrm{p} 53$, with levels of $\mathrm{p}=0.009$, $\mathrm{p}=0.035$ and $\mathrm{p}<0.001$, respectively (Figure 2 ). There was no association between the E-cadherin expression and age. The scores for the Kolmogorov-Smirnov test relating E-cadherin imunoreactivity and clinicopathological features in invasive ductal breast carcinoma are shown in Table II.

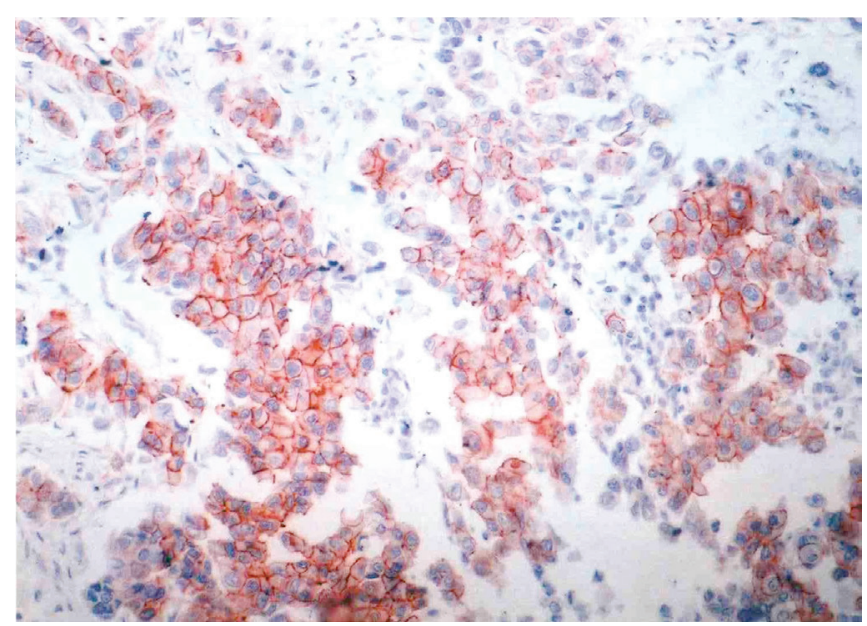

Figure 1. E-cadherin membranous staining in invasive ductal breast carcinoma (Immunoperoxidase, original magnification X200).

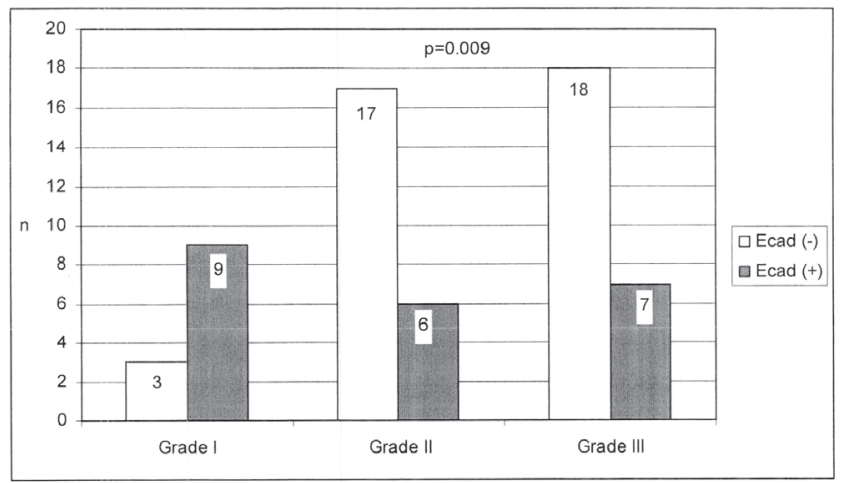

Figure 2.The presence of E-cadherin interms of the histological grade.

Table II. E-cadherin imunoreactivity and clinicopathological features in invasive ductal breast carsinoma.

\begin{tabular}{|c|c|c|c|c|c|c|c|}
\hline Features & E-cadherin(-) & $\%$ & E-cadherin $(+)$ & $\%$ & E-cadherin $(++)$ & $\%$ & P-value" \\
\hline \multicolumn{8}{|l|}{ Age(yrs) } \\
\hline$>40(n=46)$ & 30 & 65.3 & 10 & 21.7 & 6 & 13.0 & \multirow[t]{2}{*}{$\mathrm{p}=1.000$} \\
\hline$<40(n=14)$ & 9 & 64.3 & 4 & 28.6 & 1 & 7.1 & \\
\hline \multicolumn{8}{|l|}{ Histological Grade } \\
\hline I $\quad(n=12)$ & 4 & 33,3 & 4 & 33.3 & 4 & 33.3 & \\
\hline II $(n=23)$ & 17 & 73.9 & 4 & 17.4 & 2 & 8.7 & \\
\hline III $(\mathbf{n}=\mathbf{2 5})$ & 18 & 72.0 & 6 & 24.0 & 1 & 4.0 & \\
\hline LI-Positive (n=30) & 25 & 83.4 & 4 & 13.3 & 1 & 3.3 & \multirow{2}{*}{$\mathrm{p}=0.035$} \\
\hline LI-Negative $(n=30)$ & 14 & 46.7 & 10 & 33.3 & 6 & 20.0 & \\
\hline p53 (+) & 32 & 96.6 & 1 & 3.0 & 0 & 0.0 & \multirow{2}{*}{$\mathrm{P}<0.001$} \\
\hline p53 (-) & 7 & 25.9 & 13 & 48.2 & 7 & 25.9 & \\
\hline
\end{tabular}

*Kolmogorov-Smirnov test, LI: lymphatic invasion 
The clinicopathologic data including age, ER, PgR, p53 and c-erb-B2 positivity and lymphatic invasion are shown in Table I. There was no correlation between the statuse of the axillary lymph metastases and age, histological grade, ER, or p53. Significant associations were observed between PgR and c-erb-B2 expression and the status of the axillary lymph metastases ( $\mathrm{p}=0.009, \mathrm{p}=0.001$, respectively). $\mathrm{p} 53$ staining was always nuclear and was considered specific only when homogeneous. The p53 staining was positive for invasive ductal breast carcinomas (55\%). E-cadherin staining was not evident 39/60 (65\%) in invasive ductal breast carcinomas. ER, PgR, p53, and c-erb-B2 signal were positive for 36/60 (60\%), 26/60 (43.3\%), 33/60 (55\%), and 29/60 (48.3\%) of patients, respectively.

\section{Discussion}

We investigated the expression of four biological markers associated with prognosis of 60 invasive ductal carcinomas (c-erb-B2, p53, ER and PgR) and assessed the relationship between these markers and E-cadherin expression. In this study we have shown that decreased E-cadherin expression is frequent in breast cancer. Breast cancer is one the most common cancers among women. There are various benign and malignant breast lesions that can be difficult to differentiate histologically and which, therefore, can cause diagnostic problems. Metastasis is the most important cause of morbidity and mortality in this disease [1-3]. Axillary lymph node metastasis is one of the important metastatic routes of breast carcinoma. As local metastases, the synchronous axillary metastases may represent the potentially metastatic breast cancer cells much better than the primary tumor.

Variable clinical outcome of patients with breast cancer has stimulated the search for powerful prognostic markers which can predict tumor behavior. Although axillary lymph node status still remains the most important prognostic factor, a long list of potential prognostic biomarkers has now been identified $[3,7,15]$.

E-cadherin inactivation in breast cancer has been shown to be strongly associate with ductal breast cancer. Most of the previous studies have indicated that the overall survival and disease-free survival of the breast cancer patients had tumors significantly decreased with altered E-cadherin expression. The effect on survival seems to be most relevant in axillary node negative patients and also in grade III ductal carcinomas of the breast. Since, tumor grade and lymph node status have strong association with prognosis, it seems that E-cadherin expression correlates with prognosis of breast cancer [1-5,10]. E-cadherin, located on the long arm of chromosome 16, is a cell adhesion molecule between epithelial cells. E-cadherin is a $120 \mathrm{kD}$ transmembrane glycoprotein. Cell adhesion molecules are important in the regulation of cell differentiation and morphogenesis. The cell adhesion molecule E-cadherin (epithelial cadherin) is a member of the cadherin family of transmembrane glycoproteins that mediate calcium dependent homophilic cell-cell adhesion. E-cadherin acts as an invasion suppressor molecule $[7,11,12]$. Invasion is the hallmark of malignancy. Half of all cancer deaths are either directly or indirectly due to local invasion and metastasis in distant organs. The first step in invasion and metastasis is the detachment of cancer cell from the primary tumor $[12,13,15]$. The E-cadherin gene is frequently lost or mutated in tumors. Loss of E-caderin expression is thought to facilitate tumor cell detachment from primary tumor. Reduction or loss of expression of either E-cadherin is associated with invasion, metastasis, and poor prognosis in several types of human malignancies, including breast cancer $[13,14]$.

The p53 protein has many functions. It acts as a transcription factor by both transactivating some genes and suppressing transcription of others. The most important action in prevention of tumour formation and progression is probably the "guardian of the genome" function. Genetic abnormalities of the p53 tumor suppressor gene are among the most frequent mutations in tumorigenesis. p53 protects cells from DNA damage by inducing either growth arrest or apoptosis in response to stress signals $[5,6,9]$.

In this study we analyzed immunohistochemically the expression of p53 and E-cadherin proteins in the axillary lymph node metastases and assessed the relationship between clinicopathologic variables. We stained the primary tumor using IHC produres. Products of $\mathrm{p} 53$, E-cadherin, c-erbB-2 genes, ER, and PgR have been studied immunuhistochemically in 60 patients.

The loss of hormone receptor in axillary nodal metastasis may partly explain why some patients with hormone receptor-positive primary tumors are reported to respond poorly to endocrine therapy $[11,15,16]$.

Breast cancer is a kind of hormone-dependent tumor; the expression of ER receptor and PgR receptor is the important indicator for efficacy and prognosis in patients with endocrine therapies [6,7].

Several retrospective studies demonstrated ER, PgR, and HER2 status instability between primary breast cancer and 
synchronous axillary lymph node metastases $[7,16]$. In this study, it was found that there was statistically a significant association between PgR status and c-erb-B2 expression and lymph node metastases $(\mathrm{p}=0.009, \mathrm{p}=0.001$, respectively). We found no significant correlation between grade, age, ER, and $\mathrm{p} 53$ expression with lymph node metastases. Yang et al. [17] found that expression of c-erb-B2 was positively correlated with the status of lymph node metastases. Our findings also supported the views of the Yang et al. [17] that lymph node meastases were corelated with c-erb-B2 positivity.

Cobanoglu et al. [18] and Rakha et al. [19] reported that no correlation was observed when comparing E-cadherin expression and age and lymph node status. Jeschke et al. [20] who found that a strong expression of E-cadherin in carcinoma in situ was demonstrated. Expression of E-cadherin was moderate in invasive carcinomas without metastases. However, very weak expression of E-cadherin in primary carcinomas with lymph node metastases was detected. Park et al. [1] who found an associated between E-cadherin and lymph node metastases. They have shown that abnormal E-cadherin expression in primary tumours with lymph node metastases is a potential prognostic factor. Jones et al. [21] and Hunt et al. [22] reported that a strong correlation between reduced membrane levels of E-cadherin and the presence of lymph node metastases. We also found similar association. Our findings suggest that reduced E-cadherin might play a potential role in invasive ductal breast carcinomas with axillary lymph node metastases. Evluation of E-cadherin expression in primary invasive breast carcinomas with axillary lymph node metastases seems to provide additional prognostic information [15]. Harigopal et al. [23] have shown that a strong E-cadherin expression in lymph node metastases was highly predictive of improved survival, whereas expression in primary tumours was not.

Howard et al. [24] reported that the E-cadherin expression was not associated with tumor grade. Our results agree with those of Charpin et al. [25] and Parker et al. [26] who found that reduced E-cadherin expression has been associated with high histological grade. The independence of E-cadherin expression supports the notion that it assists aggressive tumor growth by providing a support structure for cells to adhere and accelerates invasion and metastasis.

There was an association with E-cadherin and p53 in our study. Howard et al. [24] did not found any relationship between p53 and E-cadherin expression in contrast with the reports by Bukholm et al. [12] and Charpin et al. [25] reported that the $\mathrm{p} 53$ protein has a role in E-cadherin protein expression in breast carcinomas. Hosaka et al. [27] reported that the general apoptosis-related proteins, p53, BcI-2 and E-cadherin, rather than breast cancer-specific factors play important and cooperative roles in comedonecrosis formation in early invasive breast cancers [24,27].

\section{Conclusion}

In this study, we used prognostic biomarkers, age, tumor grade and lymph node status for prognostic purposes. Our study confirms that decreased expression of E-cadherin, p53, ER, PgR and presence of expression c-erb-B2 proteins are associated with agressive clinical behavior in invasive ductal breast carcinomas. In addition to such parameters as lymph node status, histologic type and grade, the hormone receptors, E-cadherin, p53 and c-erb-B2 of a primary breast carcinoma carry clinical utility in determining patient treatment options and overall prognosis. Validity of the prognostic significance of E-cadherin alteration and coexpression of E-cadherin and other biomarkers needs a prospective study on a much larger population of the patients.

\section{References}

1. Park D, Karesen R, Ulrika A, Noven T, Sauer T. Expression pattern of adhesion molecules (E-cadherin, alpha-, beta-, gamma-catenin and claudin-7), their influence on survival in primary breast carcinoma, and their corresponding axillary lymph node metastasis. APMIS 2007;115:52-65. doi: 10.1111/ j.1600-0463.2007.apm_524.x

2. Kovacs A, Dhillon J, Walker R A. Expression of P-cadherin, but not E-cadherin or N-cadherin, relates to pathological and functional differentiation of breast carcinomas. Mol Path 2003;56:318-22. doi:10.1136/mp.56.6.318

3. Mohammadizadeh F, Ghasemibasir H, Rajabi P, Naimi A, Eftekhari A, Mesbah A. Correlation of E-cadherin expression and routine immunohistochemistry panel in breast invasive ductal carcinoma. Cancer Biomark 2009;5:1-8. doi: 10.3233/ CBM-2009-0551

4. Singhai R, Patil VW, Jaiswal SR, Patil SD, Tayade MB, Patil AV. E-Cadherin as a diagnostic biomarker in breast cancer. North Am J Med Sci 2011;3:227-33. doi.org/10.4048/ jbc.2013.16.1.16

5. Bukholm IK, Nesland JM, Karesen R, Jacobsen U, BorresenDale AL. Expression of E-cadherin and its relation to the p53 protein status in human breast carcinomas. Virchows Arch 1997; 431:317-21. doi: 10.1007/s004280050105.

6. Kilinc N, Yaldiz M. p53, c-erbB-2 expression and steroid hormone receptors in breast carcinoma: correlations with histopathological parameters. Eur J Gynaecol Oncol 
2004;25:606-10.

7. Yao ZX, Lu LJ, Wang RJ, et al. Discordance and clinical significance of ER, PR, and HER2 status between primary breast cancer and synchronous axillary lymph node metastasis. Med Oncol 2014;31:798. doi: 10.1007/s12032-013-0798-y

8. Bloom HJ, Richardson WW. Histological grading and prognosis in breast cancer; a study of 1409 cases of which 359 have been followed for 15 years. Br J Cancer 1957;11:359-77.

9. Ostrowski JL, Sawan A, Henry L, et al. p53 expression in human breast cancer related to survival and prognostic factors: an immunohistochemical study. J Pathol 1991;164:75-81.

10. Mahler-Araujo B, Savage K, Parry S, Reis-Filho JS. Reduction of E-cadherin expression is associated with non-lobular breast carcinomas of basal-like and triple negative phenotype. J Clin Pathol 2008;61:615-20. doi:10.1136/jcp.2007.053991.

11. Frickea E, Hermannstadtera C, Kellera G, et al. Effect of wild-type and mutant E-cadherin on cell proliferation and responsiveness to the chemotherapeutic agents Cisplatin, Etoposide, and 5-Fluorouracil. Oncology 2004;66:150-9. doi: $10.1159 / 000077442$

12. Bukholm IK, Nesland JM, Burresen-Dale AL. Reexpression of E-cadherin, a catenin and b-catenin, but not of c-catenin, in metastatic tissue from breast cancer patients. J Pathol 2000;1:190:15-9. doi: 10.1002/(SICI)10969896(200001)190:1<15:AID-PATH489>3.0.CO;2-L.

13. Gupta A, Deshpande CG, Badve S. Role of E-Cadherins in development of lymphatic tumor emboli. Cancer 2003;9:23417. doi: $10.1002 /$ cncr.11332.

14. Kim YT, Choi EK, Kim JW, Km OK, Kim SH Yang WI. Expression of E-cadherin and o-,I3-,y-catenin proteins in endometrial carcinoma. Yonsei Med J 2002;43:701-13. doi. org/10.3349/ymj.2002.43.6.701.

15. NedergaardL, HaerslevT, Jacobsen GK. Immunohistochemical study of estrogen receptors in primary breast carcinomas and their lymph node metastases including comparison of two monoclonal antibodies. APMIS 1995;103:20-4. doi:10.1111/j.1699-0463.1995.tb01074.x

16. Raica M, Cîmpean AM, Ceausu RA, et al. Hormone receptors and HER2 expression in primary breast carcinoma and corresponding lymph node metastasis: do we need both? Anticancer Res 2014;34:1435-40. doi:10.1007/s12032-0130798-y
17. Yang LF, Song ST, Li XB, et al. Expression of c-erbB2 protein and its relation to prognosis in 284 primary breast cancer patients. Zhonghua Zhong Liu Za Zhi 2006;28:294-7.

18. Cobanoglu U, Ersoz S, Turgutalp H, Reis A, Ozoran Y. Correlation of Ecadherin expression with clinicopathological parameters in breast carcinoma. Saudi Med J 2004;25:1024-7.

19. Rakha EA, Abd EI Rehim D, Pinder SE, Lewis SA, Ellis IO. E-cadherin expression in invasive non-lobular carcinoma of the breast and its prognostic significance. Histopathology 2005;46:685-93. doi:10.1111/j.1365-2559.2005.02156.x.

20. Jeschke U, Mylonas I, Kuhn C, et al. Expression of E-cadherin in human ductal breast cancer carcinoma in situ, invasive carcinoma, their lymph node metastasis, their distant metastasis, carcinomas with recurrence and in recurrence. Anticancer Res 2007;27:1969-74.

21. Jones J1, Royall JE, Walker RA. E-cadherin relates to EGFR expression and lymph node metastasis in primary breast carcinoma. Br J Cancer 1996;74:1287-41. doi:10.1038/ bjc. 1996.522 .

22. Hunt NCA, Douglas-Jones AG,Jasani B, Morgan JM, Pignatelli M. Loss of E-cadherin expression associated with lymph node metastases in small breast carcinomas. Virchows Archiv 1997;430:285-9.

23. Harigopal M, Berger AJ, Camp R1, Rimm D1, Kluger HM. Automated quantitative analysis of E-cadherin expression in lymph node metastases is predictive of survival in invasive ductal breast cancer. Clin Cancer Res 2005; 11:4083-9.

24. Howard EM, lau SK, lyles RH, et al. Correlation and expression of p53, HER-2, vascular endothelial growth factor (VEGF), and e-cadherin in a high-risk breast-cancer population. Int $\mathrm{J}$ Clin Oncol 2004;9:154-60. doi:10.1007/s10147-004-0386-4.

25. Charpin C, Garcia S, Bouvier C, et al. E-cadherin quantitative immunocytochemical assays in breast carcinomas. J Pathol 1997;181:294-300. doi:10.1002/(SICI)10969896(199703)181:3<294:AID-PATH772>3.0.CO;2-V.

26. Parker C, Rampaul RS, Pinder SE, et al. E-cadherin as a prognostic indicator in primary breast cancer. Br J Cancer 2001;85:1958-63. doi: 10.1054/ bjoc.2001.2178.

27. Hosaka N, Ryu T, Cui W, et al. Relationship of p53, BcI-2, $\mathrm{Ki}-67$ index and E-cadherin expression in early invasive breast cancers with comedonecrosis as an accelerated apoptosis. J Clin Pathol 2006;59:692-8. doi:10.1136/jcp.2005.030296. 